Bangladesh J. Plant Taxon. 26(1): 117-126, 2019 (June)

(C) 2019 Bangladesh Association of Plant Taxonomists

\title{
ETHNOMEDICINAL USES OF PLANTS BY SANTAL TRIBAL PEOPLES AT NAWABGANJ UPAZILA OF DINAJPUR DISTRICT, BANGLADESH
}

\author{
Most. Rojuba Khatun and A.H.M. Mahbubur Rahman* \\ Plant Taxonomy Laboratory, Department of Botany, Faculty of Life and Earth Sciences, \\ University of Rajshahi, Rajshahi-6205, Bangladesh
}

Keywords: Medicinal plants; Traditional knowledge; Nawabganj; Dinajpur; Bangladesh.

\begin{abstract}
Ethnobotanical investigation on traditional medicinal plants used by Santal tribal people of Nawabganj upazila of Dinajpur district, Bangladesh was documented. Frequent field trips were made during January to December 2018 to record ethnobotanical data by interviewing Santals of various age group, mostly ranging between 20-76 years, including the traditional healers. A total of 105 plant species under 97 genera belonging to 57 families were recorded which are used by the Santals for the treatment of 67 ailments. Out of these plant species $44 \%$ belonged to herbs, $28 \%$ trees, $18 \%$ shrubs, $10 \%$ climbers. In herbal formulations, leaves were found to be mostly used (29\%) followed by roots $(12 \%)$, fruits $(12 \%)$, whole plant $(10 \%)$, seeds $(9 \%)$, barks $(9 \%)$, stems $(5 \%)$, flowers $(4 \%)$, latex $(2 \%)$, rhizomes $(2 \%)$, petioles $(2 \%)$, gums $(2 \%)$, bulbs $(1 \%)$, tubers $(1 \%)$, pods $(1 \%)$ and buds $(1 \%)$. The Santal medicinal wealth have been presented with scientific name, family, Bangla name, Santal name, part(s) used, ailments to be treated and formulations. This study also provides data on diversity, distribution and habitats for conservation and prioritization of the medicinal plants.
\end{abstract}

\section{Introduction}

The use of plants and animals as source of medicine and food is as old as humanity. Health and diseases are coeval with life. By necessity man has undoubtedly always been concerned with the question of health and survival and has sought within the framework of his knowledge, solution to problem of illness (Rubin, 1960). The herbal occupied a distinct place in the life right from the primitive period to today and the primitive or ethnic populations have their own medical lore, and some of their therapeutic practices have found place in today's medical knowledge (Jain, 1995). This traditional knowledge is useful to develop new food sources. Exploration of natural resources and documentation of traditional knowledge is necessary.

Even today, traditional medicine is still the predominant means of health care in developing countries where about $80 \%$ of their total population depends on it for their well being. Plants are the basis for the development of modern drugs and medicinal plants have been used for many years in daily life to treat disease all over the world. However, the knowledge of medicinal plant is rapidly dwindling due to the influence of Western lifestyle, reducing in number of generations to carry on the use of plant species in traditional medicine which has increased the interest throughout the world. World Health Organization estimates that $80 \%$ of populations from many countries are using traditional of folk medicine to cure various ailments (WHO, 1991).

Over the past two decades several medicinal and ethno-botanical studies in Bangladesh have been carried out by Alam (1992); Alam et al. (1996); Anisuzzaman et al. (2007); Choudhury and Rahmatullah (2012); Faruque and Uddin (2014); Khan (1998); Khisha (1996) and Yusuf et al. (2006, 2009). However, the studies on traditional knowledge of medicinal plants of this country is

*Corresponding author, Email: drrahmanahmm@ru.ac.bd, drrahmanahmm@gmail.com 
very incomplete. The tribal people of Nawabganj, Dinajpur mostly rely on traditional medicines directly based on plant materials (Ali, 1980). The present work is an attempt to explore the traditional knowledge of medicinal plants in Nawabganj upazila of Dinajpur district, Bangladesh. In this study the local uses of plants recorded from the traditional practitioners to cure different diseases in Nawabganj upazila of Dinajpur district, Bangladesh are described.

\section{Materials and Methods}

\section{Study area:}

Nawabganj is an upazila of Dinajpur district which is one of the northern districts of Bangladesh. Total area of this upazila is $314.68 \mathrm{sq} \mathrm{km}$, located in between $25^{\circ} 14^{\prime}$ and $25^{\circ} 34^{\prime}$ north latitudes and in between $88^{\circ} 58^{\prime}$ and $89^{\circ} 13^{\prime}$ east longitudes. It is bounded by Parbatipur upazila on the north, Ghoraghat and Hakimpur upazilas on the south, Pirganj (Rangpur), Mithapukur and Badarganj upazilas on the east, Birampur and Phulbari upazilas on the west. Here annual average highest temperature $33 \cdot 5^{\circ} \mathrm{C}$ and lowest $10.5^{\circ} \mathrm{C}$ and annual rain fall $2,536 \mathrm{~mm}$. (BPC, 2001).

\section{Data collection:}

A total of twenty nine field trips were completed for the documentation of medico-botanical knowledge during January to December 2018. During the field interview, the information was noted in the documentation data sheet. All the information regarding plant species, biological forms, habitat, local names and uses were documented. Medicinal information was obtained through semi-structured interviews with knowledgeable Santals, such as Kabiraj and elderly persons. A total of 134 informants having age range of 20-76 years were interviewed using semistructured interview method. Professionally they were peasant, day labor, farmer, betel leaf cultivators, house wives, medicine men, small shop keepers etc. Among them 58 were female and rest 76 were male. Plant specimens were collected with flowers and fruits and processed using standard herbarium techniques (Alexiades, 1996).

\section{Identification:}

The collected specimens were identified and described up to species with the help of Hooker (1872-1897); Prain (1903); Kirtikar and Basu (1987); and Ahmed et al. (2008-2009). For plant nomenclature including the Bangla names, Huq (1986) and Pasha and Uddin (2013) were consulted.

\section{Results and Discussion}

A total of 105 plant species under 97 genera belonging to 57 families were recorded which are used for the treatment of 67 disease/ailments. Out of these plant species, $44 \%$ belonged to herbs, $28 \%$ trees, $18 \%$ shrubs and $10 \%$ climbers (Fig. 1). Leaves were (29\%) the mostly used plant parts in herbal formularies followed by roots (12\%), fruits (12\%), whole plant (10\%), seeds (9\%), barks $(9 \%)$, stems $(5 \%)$, flowers $(4 \%)$, latex $(2 \%)$, rhizomes $(2 \%)$, petioles $(2 \%)$, gums $(2 \%)$, bulbs $(1 \%)$, tubers $(1 \%)$, pods $(1 \%)$ and buds (1\%) (Fig. 2). The use of these medicinal plants by the Santals for the treatment of various disease are shown in Table 1. 


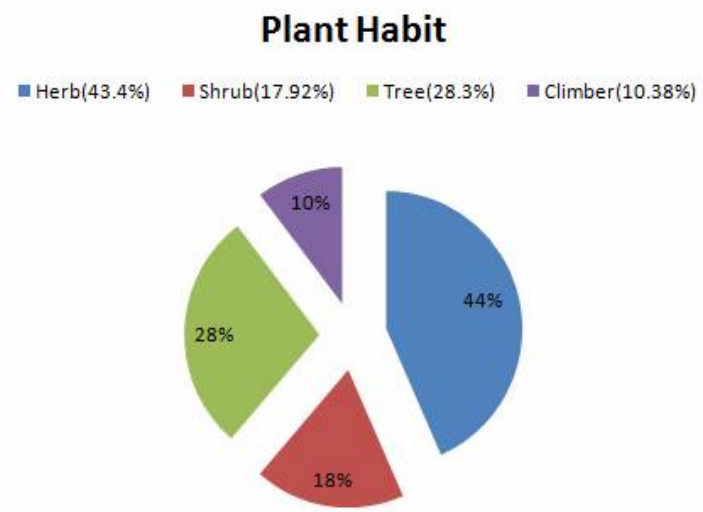

Fig. 1. Recorded plant habit in the study area.

\section{Plant parts used as medicine}

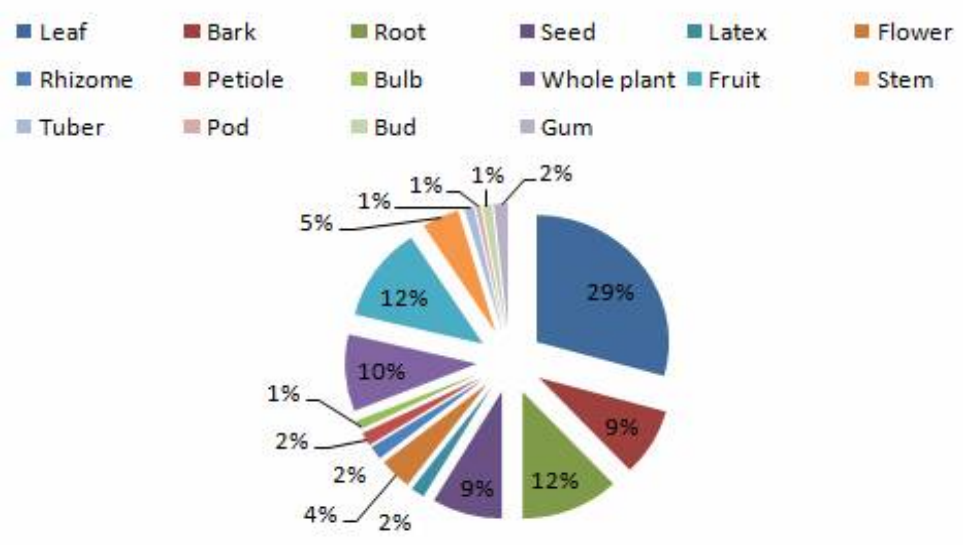

Fig. 2. Recorded plant parts used as medicine.

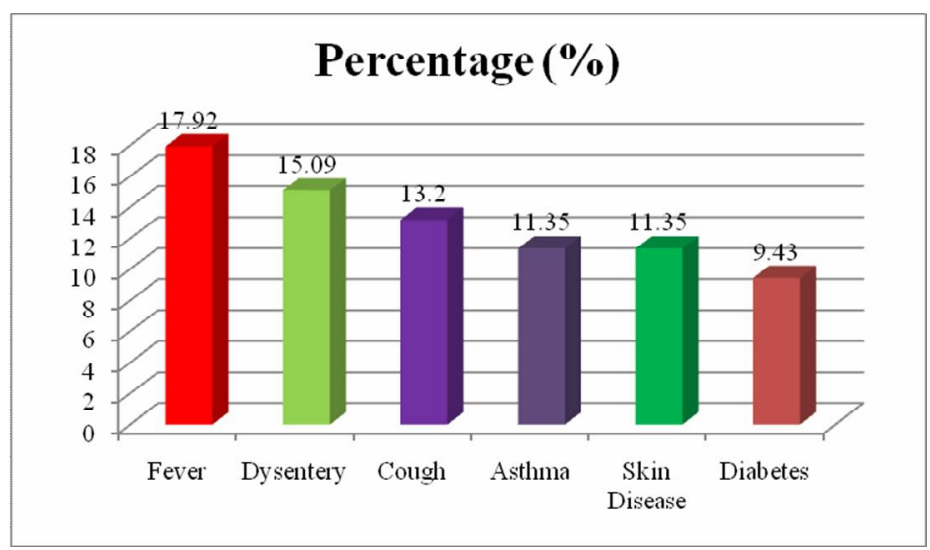

Fig. 3. Recorded dominant diseases in the study area. 


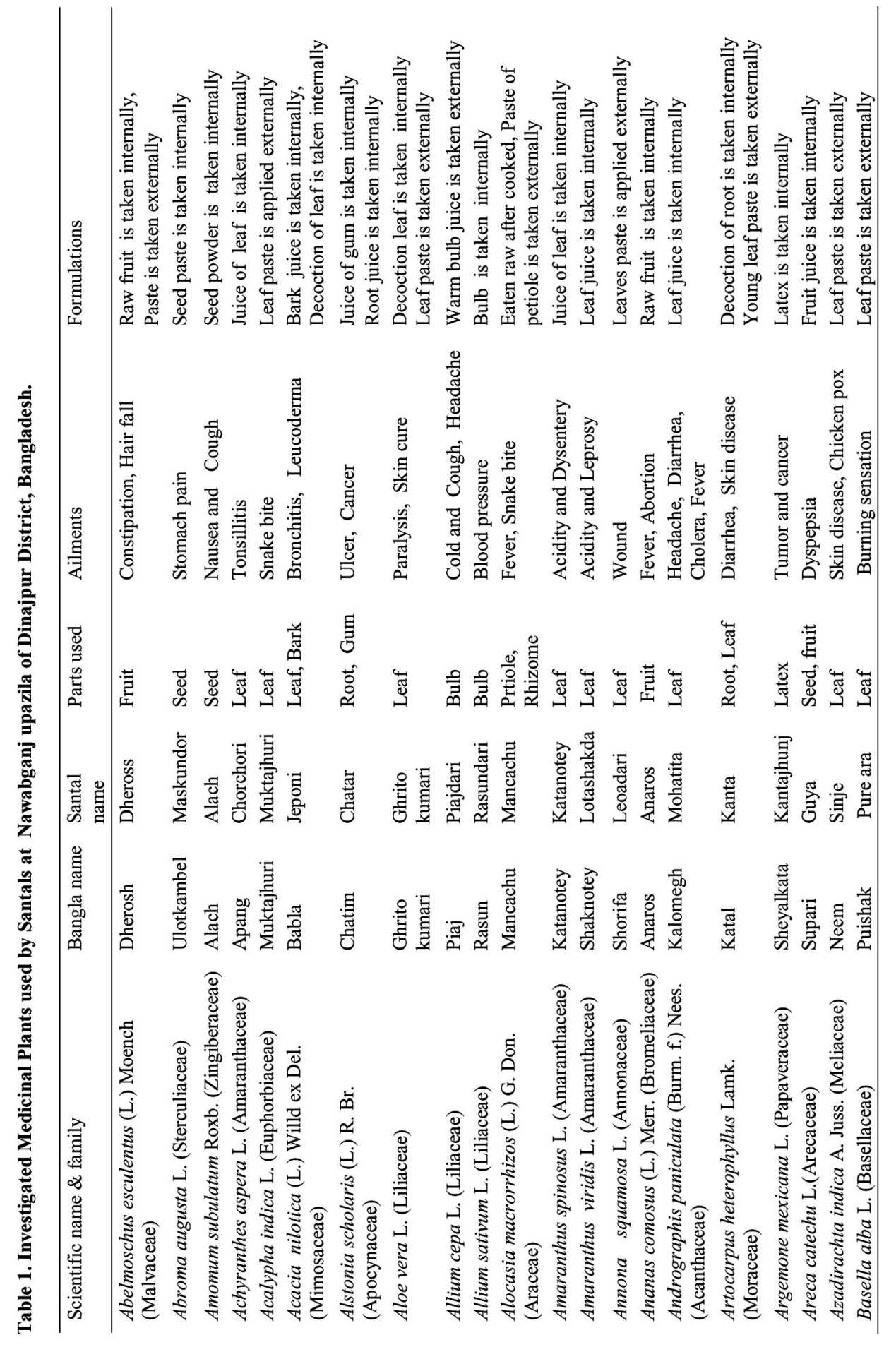




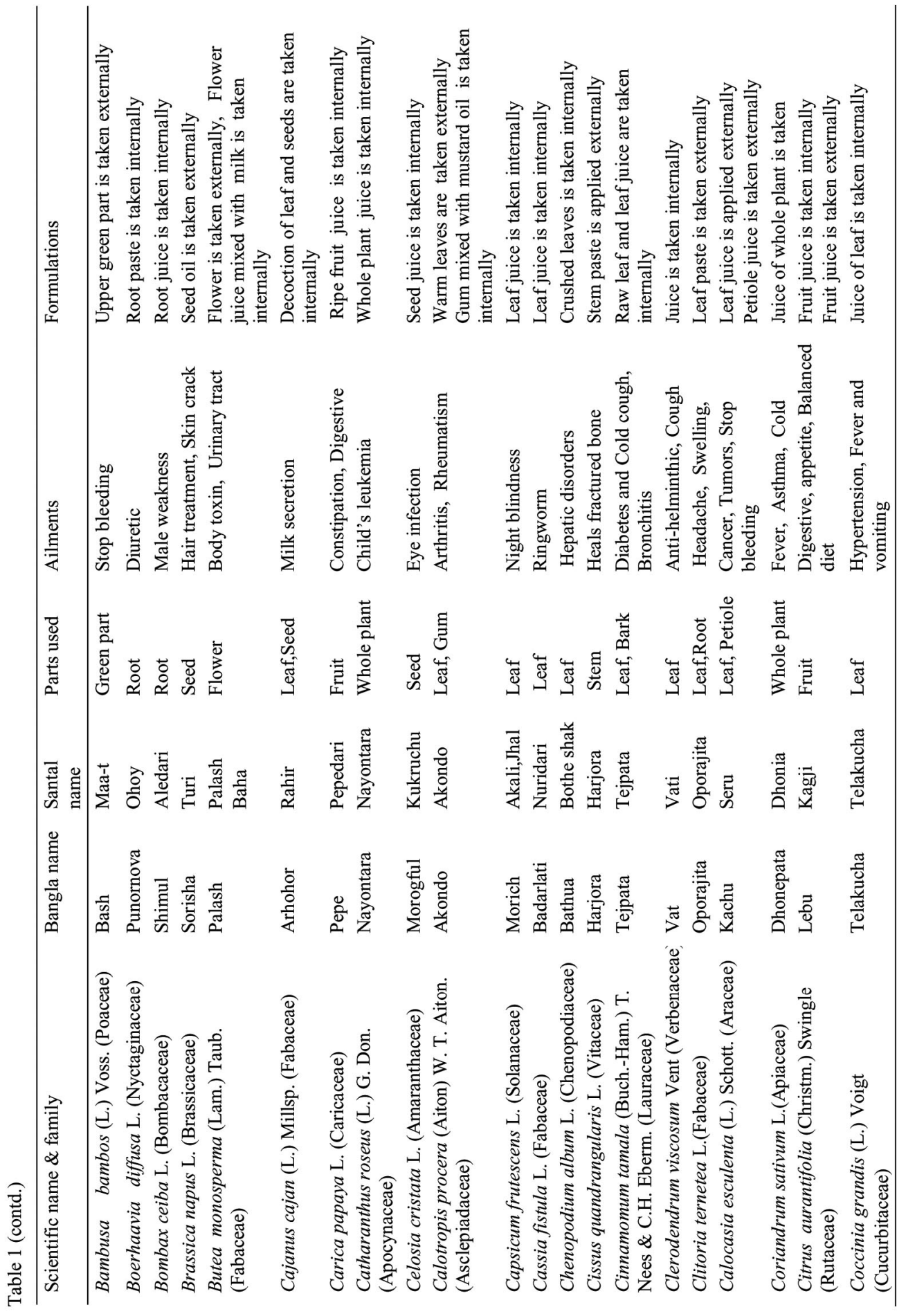




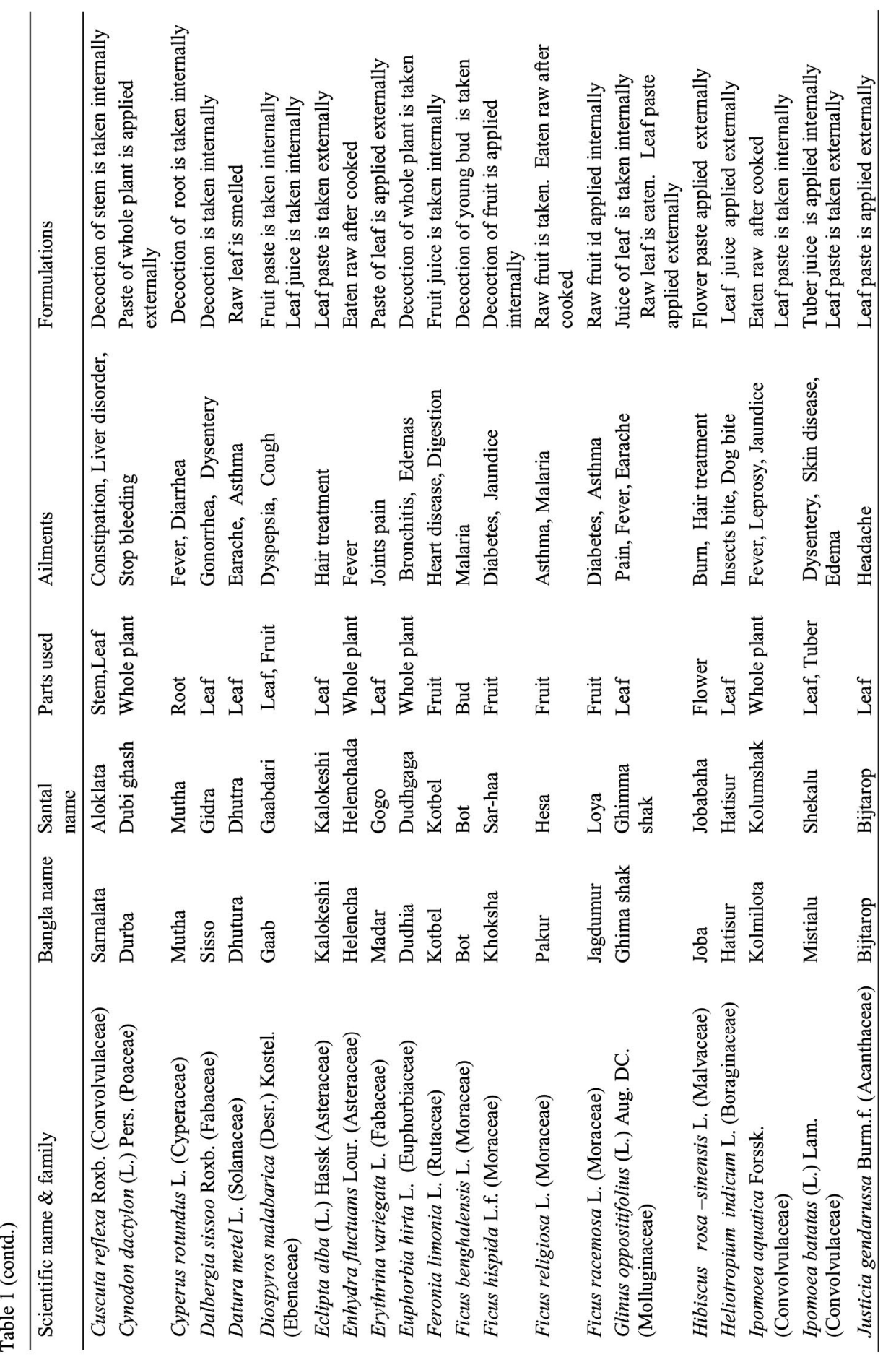




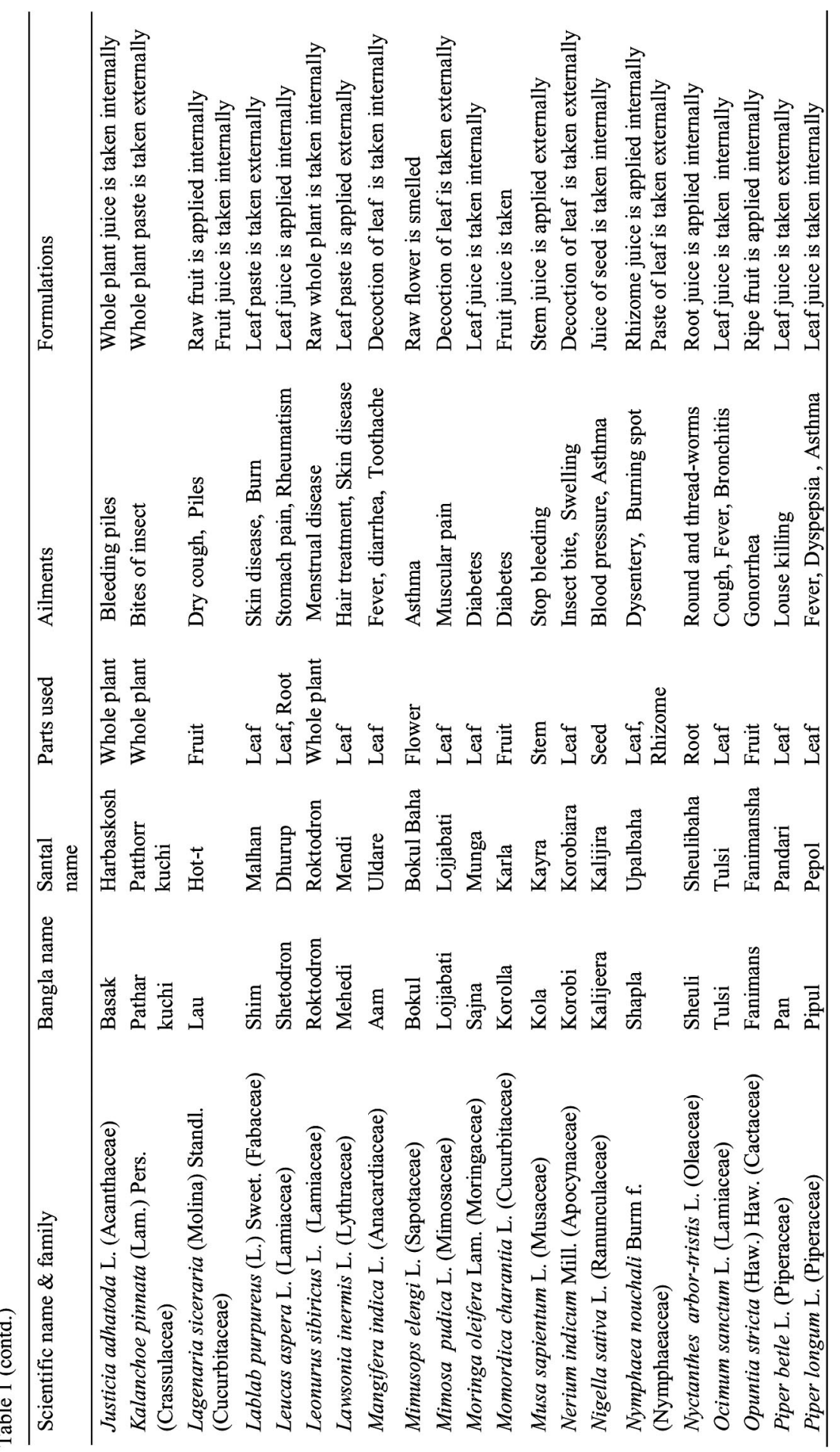




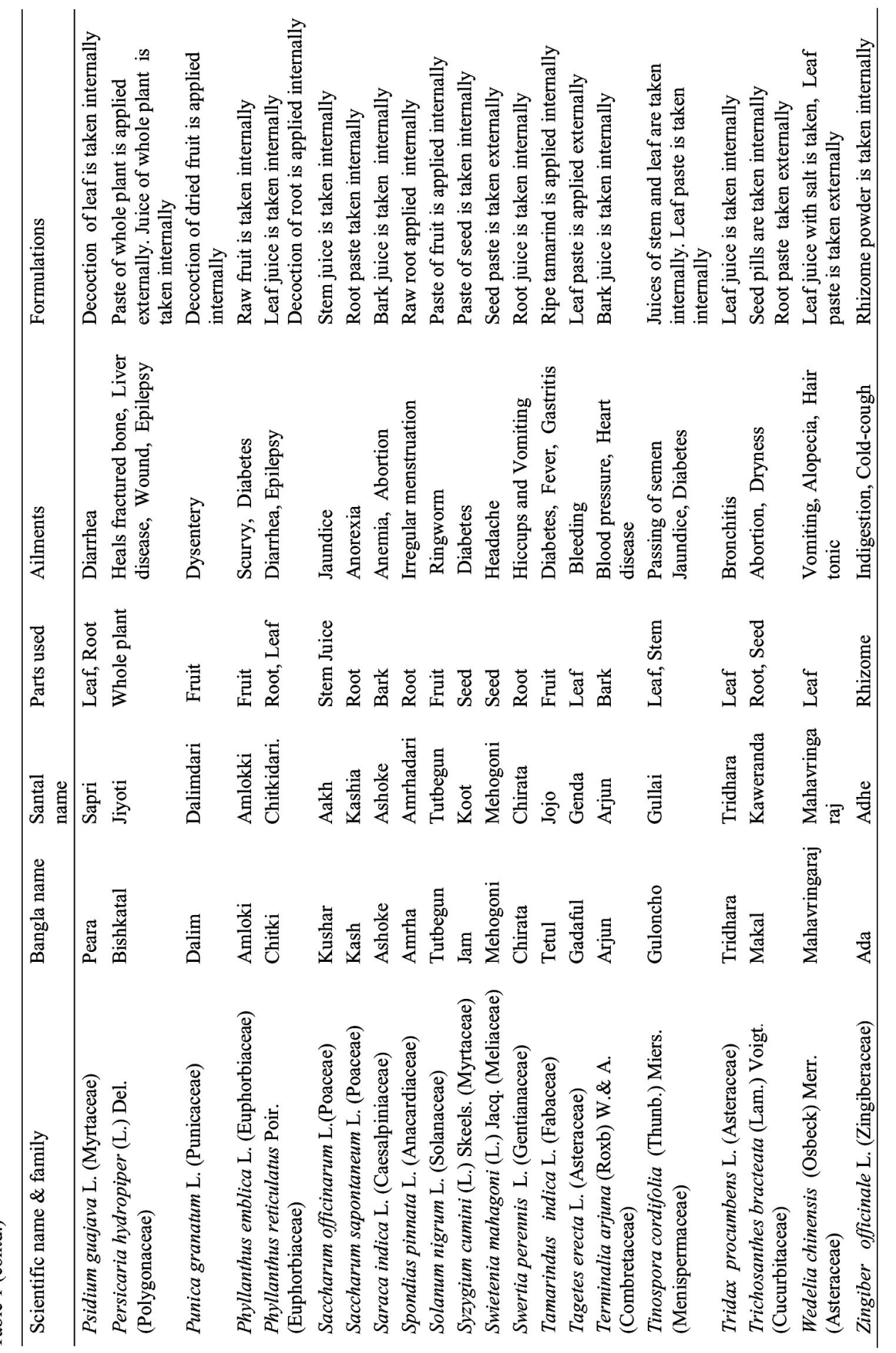


The survey has recorded 67 categories of uses of 105 medicinal plants (Table 1). This is the indication of rich knowledge of medicinal uses of plants by the Santals in Nawabganj upazila of Dinajpur district. Out of 67 categories of ailments, fever, dysentery, cough, asthma, skin disease and diabetes was dominant diseases in the study area (Fig. 3).

The most frequently used species for the treatment of different disease are shown in Table 1. This finding of common medicinal plant families in this study is in agreement with Anisuzzaman et al. (2007); Ghani (2003); Khan (1998); Choudhury and Rahmatullah (2012); Faruque and Uddin (2014); Uddin and Hassan (2014); Uddin et al., (2015), and Yusuf et al. (2006, 2009).

During the survey, the discussion, interviews and field visits with traditional healers, kabiraj, herbalists, medicine men, indicated that they have enough knowledge of medicinal uses of plant species. Traditional knowledge of tribal and local people on human disease is very important to find out new drugs for human health, also the doses and their administration needs to standardization with scientific way. Deforestation, civilization, development projects, modernizations and industrialization etc. are largely depleting the biodiversity and natural habitat of these species as well as the traditional knowledge. Conservation initiatives with in situ or ex situ conservation activities before these medicinal plant resources lost forever and training of the young generation on use and conservation of these medicinal plants are very necessary. The results of this study will play a role in primary health care of human and be helpful in further ethnobotanical studies.

\section{Acknowledgements}

The authors are grateful to the Ministry of Science and Technology (MOST), Government of the People's Republic of Bangladesh for financial support to complete this research work. The authors are also thanks to the Santal tribal practitioners in Nawabganj upazila of Dinajpur district, Bangladesh for their co-operation and help during the research work.

\section{References}

Ahmed, Z.U., Begum, Z.N.T., Hassan, M.A., Khondker, M., Kabir, S.M.H., Ahmad, M., Ahmed, A.T.A., Rahman, A.K.A. and Haque, E.U.(Eds). 2008-2009. Encyclopedia of Flora and Fauna of Bangladesh. Vols. 6-10. Asiat. Soc. Bangladesh, Dhaka.

Alam, M.K. 1992. Medical ethno-botany of the Marma tribe of Bangladesh. Economic Botany. 46(3): 330-335.

Alam, M.K.,Choudhury,J. and Hassan, M.A. 1996. Some folk formularies from Bangladesh. Bangladesh J. Life Sci. 8(1): 49-63.

Alexiades, M.N. (Ed). 1996. Selected Guidelines for Ethno Botanical Research: A Field Manual. The New York Botanical Garden, New York. 305 pp.

Ali, M. 1980. Dinajpurer Adibashi, Dinajpur Sanskrit Academy, Dinajpur, Bangladesh.

Anisuzzaman, M., Rahman, A.H.M.M., Rashid, M.H., Naderuzzaman, A.T.M. and Islam, A.K.M.R. 2007. An Ethnobotanical Study of Madhupur, Tangail. Journal of Applied Sciences Research. 3(7): 519-530.

Bangladesh Population Census (BPC) 2001. Bangladesh Bureau of Statistics (BBS); Cultural survey report of Nawabganj Upazila 2007.

Choudhury, A.R. and Rahmatullah M. 2012. Ethnobotanical study of wound healing plants among the folk medicinal practioners several district in Bangladesh. Amer.-Eur. J. Sust. Dev.6(4): 371-377.

Faruque, M.O. and Uddin, S.B. 2014. Ethnomedicinal study of the Marma community of Bandarban district of Bangladesh. Academia J. Med. Plants. 2(2): 14-25.

Ghani, A. 2003. Medicinal Plants of Bangladesh. Asiatic Society of Bangladesh, Dhaka. 
Hooker, J.D. 1872-1897. Flora of British India. Vols. 1-7. L. Reeve and Co. Ltd. London, U.K. Huq, A.M. 1986. Plant Names of Bangladesh.Bangladesh National Herbarium, BARC, Dhaka, Bangladesh. Jain, S.K. 1995. A Manual of Ethnobotany. ${ }^{\text {nd }}$ Edition. Scientific Publisher, Jodhpur, India. pp. 67-68.

Khan, M.S. 1998. Prospects of Ethnobotany and Ethnobotanical Research in Bangladesh. In: R.L. Banik, M.K. Alam, S.J. Pei and A. Rastogi (eds.), Applied Ethnobotany, BFRI, Chittagong, Bangladesh. pp. 24-27.

Khisha, B. 1996. Chakma Talik Chikitsa. Herbal Medicine Centre Committee, Rajban Bihar, Rajbari, Rangamati. 136 pp.

Kirtikar, K.R. and Basu, B.D. 1987. Indian Medicinal Plants. Vols. 1-4. Lalit Mohan Basu, Allahabad, Jayyed Press, New Delhi, India.

Pasha, M.K. and Uddin, S.B. 2013. Dictionary of Plant Names of Bangladesh (Vascular Plants).JanokalyanProkashani.Chittagong, Dhaka, Bangladesh.

Prain, D. 1903. Bengal Plants. Vols. 1-2. Botanical Survey of India. Calcutta, India.

Rubin, V. 1960. Preface in culture, Society and health, Annals of New York academic science. 84: 783-1060.

Uddin, M.Z., Kibria, M.G., and Hassan, M.A. 2015. Study of Ethnomedicinal Plants used by local people of Feni District, Bangladesh. J. Asiat. Soc. Bangladesh, Sci. 41(4): 735-757.

Uddin, M.Z. and Hassan, M.A. 2014. Determination of informant consensus factor ethnomedicinal plants used in Kalenga forest, Bangladesh. Bangladesh J. Plant Taxon. 21(1): 83-91.

WHO 1991. "Guideline for Assessment of the Herbal Medicines" Programme on Traditional. WHO, Geneva, pp. 56-91.

Yusuf, M., Wahab, M.A., Choudhury, J.U. and Begum, J. 2006. Ethno-medico-botanical knowledge from Kaukhali proper and Betunia of Rangamati district. Bangladesh J. Plant Taxon. 13(1): 55-61.

Yusuf, M., Begum, J., Hoque, M.N. and Choudhury, J.U. 2009. Medicinal plants of Bangladesh-Revised and Enlarged. Bangladesh Coun. Sci. Ind. Res. Lab. Chittagong, Bangladesh. 